\title{
PERSEPSI TENTANG AKUNTANSI: STUDI KUALITATIF DALAM KONTEKS STIKOM SURABAYA
}

\author{
Eka Yuliana ${ }^{1}$ \\ Sekolah Tinggi Ilmu Eknomi Indonesia (STIESIA) Surabaya \\ Lyla.juhara@gmail.com \\ Akhmad Riduwan ${ }^{2}$ \\ Sekolah Tinggi Ilmu Eknomi Indonesia (STIESIA) Surabaya \\ akhmadriduwan@stiesia.ac.id \\ Lilis Ardini ${ }^{3}$ \\ Sekolah Tinggi Ilmu Eknomi Indonesia (STIESIA) Surabaya \\ lilisardini@stiesia.ac.id
}

\begin{abstract}
Accounting is one of favorite subject for high scholl students who are interested in the socio-humanistic field of study. The accountant profession is also considered by community having broader job opportunities. However, accounting professionals are still limited, as in Stikom Surabaya where the numbers of new accounting students are lesss than other majors. This fact needs to be explored so accurate reasons can be identified and particular information on the less interest on studying accountancy in Stikom Surabaya can be provide for further considerations. Therefore, this study applied qualitative analysis with an interpretive approach. The techniques for data collection where data collection where through Focus Group Discussion (FGD) and interviews. The respondents where 29 people consisting of high school students (class) XII, prospective applicants, accounting students in all levels, non accounting students, accounting teachers, school counsellors and parents. As the resulst, this study councluded that each participant had different perceptions on accounting study and the accounting profession. Most respondents argued that accounting profession dealt with number, had in door office activities, a boring job and serious profession and had no sense of humor. Overall, an accountants is considered as an introvert person. The respondent also conveyed that accounting subject was difficult owing to many calculations and formulas, that the accounting carrier was not prospective for the next 10 years and that the proffesion had highest risk that other professions. Moreover, the respondents mostly had no information that Stikom Surabaya provides accounting study. They just acknowledged that Stikom was imaged as the campus of engineering, information technology and design.
\end{abstract}

Keyword : Accountant profession, accounting department, perception about accounting

\begin{abstract}
ABSTRAK: Jurusan akuntansi adalah salah satu jurusan favorit yang diminati siswa SMA pada bidang Soshum dan profesi akuntan adalah profesi dengan peluang kerja yang luas. Akan tetapi tenaga profesi akuntan masih minim dan hal ini juga berdampak pada Stikom Surabaya dengan jumlah mahasiswa baru pada jurusan akuntansi paling sedikit peminatnya dibanding dengan jurusan lainnya. Hal ini perlu digali dari persepsi masyarakat tentang akuntansi yaitu profesi dan kuliah pada jurusan akuntansi agar dapat memberikan informasi penyebab tentang sedikitnya minat studi pada jurusan akuntansi Stikom Surabaya. Surabaya. Analisis kualitatif dengan pendekatan intrepretif dilakukan dalam penelitian ini. Teknik yang digunakan adalah dengan
\end{abstract}


Focus Group Discussion (FGD) dan wawancara. Sejumlah 29 informan diwawancarai yang terdiri dari siswa SMA kelas XII, calon pendaftar, mahasiswa aktif jurusan akuntansi semua tingkat, mahasiswa aktif jurusan non akuntansi, guru akuntansi, guru bimbingan karir dan orang tua. Hasil penelitian diperoleh bahwa persepsi tentang akuntansi dan profesi akuntan berbeda-beda. Sebagian besar informan berpresepsi bahwa akuntansi adalah pekerjaan yang hanya berkutat dengan angka dan hanya duduk di dalam ruangan sepanjang hari dan profesi akuntan adalah profesi yang membosankan, terlalu serius, tidak memiliki rasa humor dan akuntan adalah pribadi yang introvert. Mata pelajaran akuntansi itu sulit dan banyak hitungan dan rumusnya dan karir pada bidang akuntansi tidak prospek untuk 10 tahun kedepan dan resikonya lebih besar dari profesi lainnya. Hasil penelitian juga menunjukkan bahwa sebagian besar informan menyatakan tidak mengetahui bahwa di Stikom Surabaya terdapat jurusan akuntansi dan menurut mereka imagenya adalah kampus teknik, teknologi informasi dan desain.

Kata Kunci: Profesi Akuntan, Kuliah Jurusan Akuntansi, Persepsi Tentang Akuntansi

\section{Pendahuluan}

Profesi di bidang akuntansi merupakan salah satu profesi yang memiliki peluang tinggi dalam mendapatkan pekerjaan. Saat ini jumlah tenaga profesi akuntan di Indonesia terbilang masih sedikit, hal ini dikarenakan tidak semua lulusan akuntansi akan langsung menggeluti profesi akuntan. Menurut berita yang ditulis oleh (berita wartaekonomi.co.id, 2018), hal yang sama juga disampaikan bahwa jumlah tenaga akuntan di Indonesia masih minim apabila dibandingkan dengan jumlah usaha mikro, kecil, dan menengah (UMKM).

Akuntansi merupakan salah satu jurusan yang paling banyak diminati pada Perguruan Tinggi Negeri (PTN) di Indonesia, beberapa jurusan favorit lainnya adalah hukum, manajemen, komunikasi dan administrasi. Kelima jurusan tersebut dikategorikan kedalam dan khususnya jumlah mahasiswa pada Jurusan S1 Akuntansi secara kuantitatif paling sedikit jika dibandingkan dengan jurusan lainnya. Dengan adanya fenomena ini, maka perlu digali lebih mendalam terkait persepsi tentang profesi akuntan dan kuliah di jurusan akuntansi terhadap pilihan mereka untuk melanjutkan studi pada jurusan akuntansi.

Persepsi positif dan negatif tentang akuntansi berhubungan erat bidang ilmu sosial, sehingga hal ini menyebabkan persaingan semakin ketat (berita kompasiana.com, 2018). Berdasarkan survei nasional Tempo pada tahun 2017 terhadap 859 informan yang keseluruhannya siswa SMA kelas XII ditemukan bahwa jurusan akuntansi adalah jurusan favorit kedua setelah jurusan Teknologi Informasi / Ilmu Komputer dari dua belas jurusan yang masuk dalam peringkat jurusan yang paling banyak diminati (berita Tempo.co, 2018). Salah satu alasan mengapa akuntansi menjadi jurusan yang paling banyak peminatnya adalah karena prospek karier yang menjanjikan.

Akan tetapi hal ini berbeda dengan jurusan akuntansi di Stikom Surabaya pada kenyataannya data 4 tahun terakhir yaitu tahun 2015 sampai dengan tahun 2018 menunjukkan bahwa jumlah mahasiswa Stikom Surabaya belum dapat memenuhi target terhadap pilihan mereka untuk melanjutkan studi pada jurusan akuntansi. Persepsi positif ditunjukkan dalam penelitian Erwanto et al., (2015) yang menyatakan bahwa persepsi mahasiswa mengenai profesi akuntan berpengaruh signifikan positif terhadap pilihan mahasiswa untuk masuk jurusan akuntansi. Sedangkan persepsi negatif ditunjukkan dalam penelitian yang dilakukan oleh Malthus dan Fowler (2009) memberikan hasil bahwa 
akuntansi adalah pekerjaan yang hanya berkutat dengan angka-angka dan hanya duduk di dalam ruangan sepanjang hari. Sedangkan profesi akuntan adalah profesi yang membosankan, terlalu serius, tidak memilki rasa humor dan akuntan adalah pribadi yang introvert.

Persepsi negatif tentang profesi akuntan dan kuliah pada jurusan akuntansi terhadap pilihan mereka untuk memilih jurusan akuntansi yang berdampak pada penurunan jumlah mahasiswa akuntansi Stikom Surabaya. Penelitian sebelumnya yang telah dilakukan oleh (Kusuma, 2016; Erwanto et al., 2015) tentang persepsi akuntansi dilakukan dengan menggunakan pendekatan kuantitatif dengan informan mahasiswa akuntansi dan non akuntansi. Perbedaanya penelitian ini dilakukan dengan pendekatan kualitatif untuk memvalidasi penelitian-penelitian yang telah dilakukan. Melanjutkan penelitian tentang persepi akuntansi studi di New Zealand yang telah dilakukan oleh Malthus dan Fowler (2009), penelitian ini tidak hanya melibatkan siswa SMA dan mahasiswa aktif jurusan akuntansi dan non akuntansi, guru akuntansi dan guru penasihat karir (BK), tetapi penelitian ini menambahkan beberapa informan seperti calon pendaftar jurusan akuntansi dan non akuntansi dan orang tua.

Berdasarkan latar belakang tersebut maka rumusan masalah dalam penelitian ini adalah: Bagaimana persepsi masyarakat tentang akuntansi?

Sedangkan tujuan penelitiannya adalah:

1. Memahami dan menganalisis persepsi siswa SMA, calon pendaftar dan mahasiswa aktif tentang kuliah di jurusan akuntansi dan profesi akuntan dengan menginvestigasi:

a. Niat dan alasan untuk studi pada jurusan akuntansi

b. Niat dan alasan untuk berkarir pada profesi akuntan c. Persepsi masyarakat terhadap profesi akuntan

2. Memahami peran guru akuntansi, penasihat karir (BK) dan orang tua dengan menginvestigasi:

a. Persepsi mereka tentang akuntansi sebagai karir
b. Persepsi mereka dalam mempengaruhi dan mempromosikan akuntansi sebagai subyek studi dan karir

\section{Kajian Pustaka}

\section{Profesi Akuntan}

Profesi akuntan adalah semua bidang pekerjaan yang mempergunakan keahlian di bidang akuntansi, termasuk bidang pekerjaan akuntan publik, akuntan intern yang bekerja pada perusahaan industri, keuangan atau dagang, akuntan yang bekerja di pemerintah, dan akuntan sebagai pendidik. Ikatan Akuntan Indonesia (IAI) telah menetapkan sebutan Chartered Accountant (CA) sebagai kualifikasi akuntan profesional sesuai panduan standar internasional. Penetapan sebutan CA dilaksanakan dalam rangka melaksanakan tujuan pendirian pendidikan akuntan; dan mempertinggi mutu pekerjaan akuntan. Sertifikat CA diberikan kepada seseorang yang dinilai telah memenuhi kualifikasi untuk menjalankan peran sebagai Akuntan Profesional sesuai kompetensi utama dan kompetensi khusus CA. Untuk memperoleh sebutan CA, seseorang harus memenuhi persyaratan: lulus ujian sertifikasi CA Indonesia yang dilaksanakan oleh IAI, memiliki pengalaman dan/atau menjalankan praktik keprofesian di bidang akuntansi, baik di sektor pendidikan, korporasi, sektor publik, maupun praktisi akuntan publik yang data di verifikasi paling sedikit 3 (tiga) tahun di bidang akuntansi yang di peroleh dalam 7 (tujuh) tahun terakhir; dan sebagai anggota IAI. 


\section{Persepsi Tentang Profesi akuntan dan Kuliah Pada Jurusan Akuntansi}

Persepsi adalah proses seorang individu memilih, mengorganisasikan dan menafsirkan masukan-masukan informasi untuk menciptakan suatu gambaran yang bermakna tentang dunia (Kotler, 2009: 185). Penelitian tentang persepsi positif dan negatif profesi akuntan dan kuliah pada jurusan akuntansi telah dilakukan oleh beberapa penelitian terdahulu yaitu diantaranya adalah penelitian yang dilakukan Germanou et al. (2009), penelitian ini dilakukan dengan survey untuk menyelidiki persepsi mahasiswa mengenai profesi akuntan. Kuesioner diisi oleh mahasiswa perrtukaran pelajar Malaysia ke Universitas Inggris dan mahasiswa aktif di Universitas Inggris. Hasil menunjukkan bahwa kedua kelompok mahasiswa memiliki persepsi positif tentang profesi akuntan dan berkorelasi secara signifikan antara persepsi mahasiswa dengan niat mereka untuk mengejar karir pada profesi akuntan.

Selain menghasilkan persepsi positif, ada beberapa penelitian yang hasilnya adalah berupa persepsi negatif tentang profesi dan kuliah pada jurusan akuntansi, seperti peneltian yang dilakukan oleh Jackling (2002) dalam penelitiannya ingin mengetahui tentang persepsi profesi akuntan dan niat untuk menyelesaikan studi pada jurusan akuntansi, informannya adalah mahasiswa akuntansi tahun pertama pada lima perguruan tinggi. Hasil penelitian ini adalah bahwa mayoritas mahasiswa yang disurvey memiliki persepsi negatif tentang akuntansi. Yang mempengaruhi persepsi tersebut adalah pengalaman studi di perguruan tinggi, hal ini menjadi evaluasi penting bagi akuntan pendidik (dosen) dan badan profesional akuntansi.

Sejalan dengan penelitian yang dilakukan oleh Malthus dan Fowler (2009) dengan tujuan penelitian untuk memastikan persepsi siswa SMA, mahasiswa tersier di Selandia Baru, akuntan pendidik (guru akuntansi) dan penasihat karir yang dapat mempengaruhi siswa. Penelitian ini memberikan hasil bahwa akuntansi adalah pekerjaan yang hanya berkutat dengan angka-angka dan hanya duduk di dalam ruangan sepanjang hari. Sedangkan profesi akuntan adalah profesi yang membosankan, terlalu serius, tidak memilki rasa humor dan akuntan adalah pribadi yang introvert.

\section{Minat Studi Akuntansi}

Minat menunjukkan adanya suatu ketertarikan terhadap sesuatu. Menurut Crow and Crow dalam Djaali (2011:121) mengatakan bahwa "minat berhubungan dengan gaya gerak yang mendorong seseorang untuk menghadapi atau berurusan dengan orang, benda, kegiatan, pengalaman yang dirangsang oleh kegiatan itu sendiri. Minat ini dapat ditunjukkan dengan lebih menyukai sesuatu hal daripada yang lainnya ataupun dapat ditunjukkan dengan melakukan suatu aktivitas yang disenanginya. Menurut Syah (2009: 145) minat melanjutkan studi ke perguruan tinggi adalah ketertarikan siswa untuk melanjutkan studi ke perguruan tinggi yang tumbuh secara sadar dalam diri siswa tersebut. Siswa yang mempunyai ketertarikan pada perguruan tinggi akan mendorong siswa untuk melanjutkan studinya ke perguruan tinggi. Siswa tersebut akan cenderung berusaha semaksimal mungkin untuk mencapai yang dicita-citakan. Perguruan tinggi merupakan lanjutan setelah menyelesaikan pendidikan di sekolah menengah atas.

Berdasarkan tentang teori minat yang berhubungan dengan melanjutkan studi pada perguruan tinggi, telah dilakukan beberapa penelitian yang diantaranya dilakukan oleh Fauziah (2017) yaitu untuk mengetahui pengaruh prestasi belajar, lingkungan teman sebaya, persepsi siswa tentang mata pelajaran akuntansi terhadap minat melanjutkan studi ke prodi akuntansi. 
Penelitian ini dilakukan dengan pendekatan kuantitatif dengan informan siswa kelas XII IPS SMA Negeri 1 Depok. Hasil Penelitian ini menunjukkan bahwa terdapat pengaruh positif persepsi siswa tentang mata pelajaran akuntansi, prestasi belajar akuntansi dan pengaruh teman terhadap minat melanjutkan studi ke jurusan akuntansi.

\section{Pengaruh Orang Lain Untuk Studi pada Jurusan Akuntansi}

Minat melanjutkan studi ke

Perguruan Tinggi dengan jurusan tertentu, khususnya pada jurusan akuntansi salah satu faktor yang mendorong para calon pendaftar karena dorongan dari orang-orang disekitarnya, seperti karena orang tua, teman, guru akuntansi atau guru penasehat karir, dan sebagainya. Prestasi belajar, motivasi belajar dan status sosial ekonomi orang tua berpengaruh positif terhadap minat siswa untuk melanjutkan studi ke perguruan tinggi (Rahayu, 2013). Penelitian yang sama juga dilakukan oleh Sari (2014) dalam penelitiannya menunjukkan bahwa status sosial ekonomi keluarga memiliki pengaruh terhadap minat melanjutkan pendidikan ke perguruan tinggi pada siswa kelas XII Akuntansi SMKN 3 pontianak.

Hasil penelitian Sutrisno (2017) membuktikan bahwa layanan informasi studi lanjut berpengaruh terhadap minat siswa masuk perguruan tinggi. Oleh karena itu dapat dimanfaatkan sebagai bahan masukan dan pertimbangan bagi Guru Bimbingan dan Konseling agar dapat meningkatkan perannya dalam mengarahkan siswa-siswa SMK yang bermaksud melanjutkan ke perguruan tinggi setelah selesai studi. Penelitian lainnya yang dilakukan oleh Budiarti (2015) yaitu ada pengaruh lingkungan teman sebaya, kondisi sosial ekonomi orang tua, dan peran guru terhadap minat melanjutkan studi ke perguruan tinggi siswa kelas XII jurusan Administrasi Perkantoran di SMK Negeri 2 Semarang tahun ajaran 2014/2015 secara simultan maupun secara parsial.

\section{Faktor-Faktor \\ yang \\ Berpengaruh \\ Terhadap \\ Mengambil Jurusan Akuntansi dan Memilih Karir Sebagai Profesi akuntan}

Terdapat beberapa faktor yang mempengaruhi seseorang di dalam memilih jurusan akuntansi dan berkarir sebagai profesi akuntan yaitu diantaranya disebutkan di dalam penelitian sebagai berikut: Hasil penelitian menunjukkan bahwa semua faktor - faktor yang diteliti seperti penghargaan finansial, pendidik profesional, pengakuan profesional, nilai - nilai sosial, lingkungan kerja, pertimbangan pasar kerja, keluarga dan teman, instruktur akuntansi, rekan, serta personalitas adalah merupakan faktor yang menarik minat mahasiswa akuntansi pada profesi akuntan manajemen. Temuan lain juga menunjukkan mahasiswa akuntansi lebih memilih profesi akuntan perusahaan sebagai pilihan pertama karir mereka dibandingkan dengan jenis profesi akuntan yang lain (Yudhantoko, 2013).

Kusuma (2016) menyebutkan bahwa pengambilan keputusan dalam memilih program studi akuntansi dipengaruhi oleh beberapa faktor yang terbentuk, yaitu: faktor perguruan tinggi, faktor lingkungan dan faktor internal. Hasil analisis faktor terdapat 3 kelompok faktor yang menjadi faktor baru dalam penelitian ini, yaitu faktor perguruan tinggi dengan variabel lokasi, reputasi perguruan tinggi, fasilitas pendidikan, program akademik, promosi, biaya 
pendidikan, ketersediaan bantuan keuangan. Faktor lingkungan pengambilan keputusan mahasiswa dalam memilih Program Studi Pendidikan Akuntansi dengan variabel pola asuh orang tua dan bimbingan karir. Faktor internal pengambilan keputusan mahasiswa dalam memilih program studi pendidikan akuntansi dengan variabel sikap dan aspirasi. Hasil penelitian yang dilakukan Sulistyawati et al., (2013) membuktikan bahwa ada perbedaan persepsi mahasiswa dalam pemilihan karir gaji, pelatihan profesional, pengakuan keprofesionalan, lingkungan kerja dan pertimbangan pasar tenaga kerja merupakan hal-hal yang bisa menyebabkan perbedaan persepsi dalam pemilihan karir. Sedangkan nilai sosial dan kepribadian bukanlah faktor yang menyebabkan perbedaan persepsi mahasiswa.

Hsiao and Nova (2016) melakukan penelitian yang dilakukan dengan mencari faktor yang mempengaruhi generasi $\mathrm{Y}$ untuk memilih profesi akuntan sebagai karir mereka. Penelitian ini dilakukan di beberapa negara seperti USA, Australia dan Jepang. Hasilnya adalah memilih akuntan sebagai karir mereka karena dipengaruhi oleh beberapa faktor seperti kreativitas, kebebasan, lingkungan yang berubah dan dinamis, kerja yang aman, memperoleh uang, lapangan pekerjaan tersedia, dan karena pengaruh orang lain seperti teman dan guru.

\section{Metode Penelitian}

Jenis penelitian ini menggunakan metode kualitatif dengan pendekatan interpretif. Penelitian ini menggunakan pendekatan intrepretif karena peneliti ini memaknai persepsi masyarakat tentang studi akuntansi dan profesi akuntan. Pendekatan interpretif berangkat dari upaya untuk mencari penjelasan tentang peristiwa-peristiwa sosial atau budaya yang didasarkan pada perspektif dan pengalaman orang yang diteliti.Teknik pengumpulan data dalam penelitian ini adalah studi lapangan, penelitian ini dilakukan dengan terjun secara langsung ke tempat penelitian. Instrumen pengumpulan data yang dilakukan di lapangan untuk mengumpulkan data yaitu: Focus Group Discussion (FGD) dan wawancara.

\section{Focus Group Discussion} (FGD)

FGD bertujuan untuk mengumpulkan data mengenai persepsi dan pandangan peserta terhadap sesuatu, tidak berusaha mencari konsensus atau mengambil keputusan mengenai tindakan apa yang akan diambil. Fokus Diskusi Grup dilaksanakan di ruang BK untuk siswa SMA dan ruang kelas untuk mahasiswa aktif. Jadwal pertemuan FGD dalam penelitian ini disajikan pada Tabel 1. 
Tabel 1: Tabel Jadwal FGD

\begin{tabular}{lllll}
\hline No Kelompok & $\begin{array}{l}\text { Jumlah } \\
\text { Informan }\end{array}$ & Tanggal & Waktu \\
(Menit)
\end{tabular}

1. Mahasiswa Aktif

Jurusan Akuntansi Tingkat Pertama Sesi 1

8

28-Jan-19

60

Jurusan Akuntansi Tingkat Pertama Sesi 2

2

28-Jan-19

30

Jurusan Akuntansi Tingkat Tengah Sesi 1

5

28-Jan-19

30

Jurusan Akuntansi Tingkat Tengah Sesi 2

2

28-Jan-19

30

Jurusan Akuntansi Tingkat Akhir

4

12-Feb-19

90

Jurusan Non Akuntansi

4

13-Feb-19

60

2. Siswa SMA

SMA Kemala Bhayangkari Sesi 1

12

07-Feb-19

45

SMA Kemala Bhayangkari Sesi 2

4

07-Feb-19

30

SMA Hang Tuah 2 Sesi 1

13

08-Feb-19

50

SMA Hang Tuah 2 Sesi 2

5

Sumber: (Peneliti, 2019)

\section{Wawancara Mendalam (In-Dept Interview) \\ Penelitian ini menggunakan} teknik wawancara semiterstruktur. Menurut Sugiyono (2015: 35) jenis wawancara ini sudah termasuk dalam kategori wawancara mendalam (in-dept interview), dimana dalam pelaksanaanya lebih bebas bila dibandingkan dengan wawancara terstruktur. Jadwal wawancara dalam penelitian ini disajikan pada Tabel 2.

\section{Informan Penelitian}

Partisipan (informan) dalam penelitian ini adalah sebagai berikut:

a. Siswa siswi SMA kelas XII yang telah memperoleh mata pelajaran akuntansi b. Calon pendaftar jurusan akuntansi dan non akuntansi

c. Mahasiswa aktif semester pertama jurusan S1 Akuntansi dan mahasiswa jurusan non akuntansi

d. Mahasiswa aktif semester tengah jurusan S1 Akuntansi

e. Mahasiswa semester akhir yang telah menyelesaikan studi pada jurusan S1 Akuntansi

f. Orang tua calon pendaftar jurusan akuntansi dan jurusan non akuntansi

g. Guru akuntansi dan penasihat karir (BK) di SMA

Detail informan yang digunakan dalam penelitian ini disajikan pada Tabel 3. 
Tabel 2: Tabel Jadwal Wawancara

\begin{tabular}{|c|c|c|c|c|}
\hline No & Kelompok & Jumlah & Tanggal & $\begin{array}{l}\text { Waktu } \\
\text { (Menit) }\end{array}$ \\
\hline \multirow[t]{3}{*}{1.} & $\begin{array}{l}\text { Calon Pendaftar (Jurusan akuntansi dan } \\
\text { non jurusan akuntansi) }\end{array}$ & & & \\
\hline & Sesi Pertama & 2 & 08-Feb-19 & 30 \\
\hline & Sesi Kedua & 2 & 11-Feb-19 & 30 \\
\hline \multirow[t]{3}{*}{2.} & Guru BK & & & \\
\hline & Sesi Pertama & 2 & 07-Feb-19 & 60 \\
\hline & Sesi Kedua & 2 & 08-Feb-19 & 30 \\
\hline \multirow[t]{2}{*}{3.} & Guru Akuntansi & & & \\
\hline & Sesi Kedua & 2 & 08-Feb-19 & 45 \\
\hline \multirow[t]{3}{*}{4.} & Orang Tua & & & \\
\hline & Sesi Pertama & 2 & 04-Feb-19 & 30 \\
\hline & Sesi Kedua & 2 & 09-Feb-19 & 30 \\
\hline
\end{tabular}

Sumber: (Peneliti, 2019)

Tabel 3: Tabel Informan Penelitian

\begin{tabular}{|c|c|c|c|}
\hline No. & Informan & Tempat & Jumlah \\
\hline 1. & $\begin{array}{l}\text { Mahasiswa aktif } \\
\text { (Jurusan Akuntansi Tingkat pertama, tengah, } \\
\text { akhir dan Non Akuntansi) }\end{array}$ & Stikom Surabaya & 12 \\
\hline 2. & $\begin{array}{l}\text { Calon Pendaftar } \\
\text { (Jurusan akuntansi dan non jurusan akuntansi) }\end{array}$ & Stikom Surabaya & 2 \\
\hline 3 & Siswa SMA & & 9 \\
\hline 4. & Guru BK & $\begin{array}{lr}\text { SMA Kemala } \\
\text { Bhayangkari } r \\
\text { Surabaya dan SMA } \\
\text { Hangtuah 2 Sidoarjo }\end{array}$ & 2 \\
\hline 5. & Guru Akuntansi & & 2 \\
\hline 6. & Orang Tua & Stikom Surabaya & 2 \\
\hline
\end{tabular}

Sumber: (Peneliti, 2019) 
Dalam penelitian ini sumber data yang digunakan adalah sebagai berikut:

\section{Data Primer}

Data yang langsung diperoleh dari tempat penelitian melalui Fokus Group Discussion (FGD) dan wawancara dengan seluruh informan penelitian yang dipilih.

2. Data Sekunder

Data yang diperoleh dari bagian penerimaan mahasiswa baru, misalnya follow up data pendaftaran dan registrasi melalui telepon dan isian sumber informasi (angket) serta data bakat minat yang diperoleh dari BK SMA.

\section{Satuan Kajian}

Satuan kajian dalam penelitian ini adalah calon pendaftar yang merupakan siswa SMA yang telah lulus, mahasiswa aktif jurusan akuntansi tingkat pertama, tengah dan akhir serta mahasiswa aktif non jurusan akuntansi yang pernah mendaftar pada jurusan akuntansi tetapi registrasi pada jurusan selain akuntansi, siswa SMA kelas XII yang telah mendapatkan pelajaran akuntansi, guru mata pelajaran akuntansi kelas XII, guru mata pelajaran bimbingan karir kelas XII dan orang tua calon pendaftar yang memilih jurusan akuntansi dan orang tua mahasiswa aktif jurusan akuntansi tingkat pertama di Stikom Surabaya.

\section{Teknik Analisis Data}

Teknik analisis data yang digunakan dalam penelitian ini adalah analisis data kualitatif dengan menggunakan model Miles and Humberman. Miles and Huberman mengemukakan bahwa aktifitas dalam analisis data kualitaitif dilakukan secara interaktif dan berlangsung secara terusmenerus sampai tuntas, sehingga datanya sudah jenuh. Aktifitas dalam analisis data, yaitu data reduction, data display, dan conclusion drawing/verificastion.

Berikut langkah-langkah teknik analisis data dengan model Miles and Huberman:
1. Data Reduksi

Mereduksi data berarti merangkum, memilih hal-hal yang pokok, memfokuskan pada hal-hal yang penting, dicari tema dan polanya.

2. Data Display

Display yang paling sering digunakan untuk menyajikan data dalam penelitian kualitatif adalah dengan teks yang bersifat naratif.

3. Kesimpulan

Kesimpulan dalam penelitian kualitatif adalah merupakan temuan baru yang sebelumnya belum pernah ada.

\section{Teknik Pengujian Data}

Penelitian ini menggunakan teknik pengujian data dengan menggunakan uji triangulasi untuk memeriksa kesesuain data yang diperoleh di lapangan. Triangulasi adalah teknik pemeriksaan keabsahan data yang memanfaatkan sesuatu yang lain di luar data itu untuk keperluan pengecekan atau pembanding terhadap data itu (Lexy, 2009). Penelitian menggunakan triangulasi metode, triangulasi metode dilakukan dengan cara membandingkan informasi atau data dengan cara yang berdeda. Penelitian ini menggunakan metode FGD, wawancara, dan observasi. Untuk memperoleh kebenaran informasi yang handal dan gambaran yang utuh mengenai informasi tertentu, peneliti menggunakan metode wawancara semiterstuktur dalam FGD dan in depth interview. Peneliti juga menggunakan wawancara dan obervasi untuk mengecek kebenarannya. Selain itu, peneliti memberikan pertanyaan yang sama kepada beberapa informan yang berbeda untuk mengecek kebenaran informasi tersebut.

\section{Hasil dan Pembahasan}

Pada bagian hasil dan pembahasan ini akan dijelaskan hasil interpretasi atas persepsi masyarakat tentang akuntansi (kuliah dan profesi akuntan) sehingga 
dari pembahasan tersebut dapat diperoleh sebuah pemahaman dan analisis persepsi siswa SMA, calon pendaftar dan mahasiswa aktif serta peran guru SMA dan orang tua.

\section{Niat dan Alasan untuk Studi pada Jurusan Akuntansi}

Penelitian Uyar et al., (2011) menginvestigasi alasan penyebab mahasiswa memilih karir di akuntansi. Hasil temuannya menyatakan bahwa mahasiswa ingin bekerja pada bidang akuntansi karena berasumsi bahwa dapat memperoleh pekerjaan yang terbaik dan sesuai dengan kemampuan dan minat mereka. Seperti yang telah disampaikan oleh beberapa informan yang diwawancarai alasan mereka berminat melanjutkan studi pada jurusan akuntansi berikut ini:

"Saya minat ambil
jurusan akuntansi karena
dari diri sendiri, karena
saya suka
menghitung...."[Biyan,
Siswa SMA kelas XII]

"Sempat ditawari jurusan manajemen atau KPK, karena SMK dulu dari jurusan akuntansi akhirnya ambil akuntansi.'[Lutfi, Mahasiswa aktif tingkat tengah]

"Dan pada saat datang ke bagian pendaftaran lihat ada jurusan akuntansi dan waktu SMA saya suka ngitung lebih dari pada hafalan, akhirnya saya pilih akuntansi.'[Ersyva,

Mahasiswa aktif tingkat akhir]

Akuntansi memang lebih banyak menghitung, mungkin itulah yang membuat sebagian orang tidak suka dengan hitung-hitungan. Akuntansi itu hanya butuh pemahaman bukan mengahafal karena itulah yang membuat sebagian orang mungkin tidak mau mengambil jurusan akuntansi ini karena dia takut akan hitungan. Sebagian informan menyampaikan bahwa akuntansi itu sulit, berikut paparan yang mereka sampaikan:

"Saya kurang minat ke
akuntansi karena
akuntansi itu harus teliti,
saya orangnya tidak teliti
jadi saya tidak cocok.
Dan memahami
rumusnya kan sulit dan
matpelnya susah. Saya
mau ambil sejarah suka
teori." [Imrotul, siswa
SMA kelas XII]

"Saya tidak minat ke akuntansi karena untuk rumusnya tadi susah menghafalnya.'[Agathan , siswa SMA kelas XII]

"Menurut saya akuntansi itu susah dan saya kurang minat, minatnya sosiologi. Lebih suka ke teori." [Ilham, siswa SMA kelas XII]

Hasil paparan yang disampaikan oleh beberapa informan sejalan dengan hasil penelitian Malthus dan Flower (2009) yang menyatakan bahwa mahasiswa S1 berpersepsi bahwa akuntansi itu sulit dan membosankan, beban kerjanya berat dan fokus pada angka kemudian orangnya harus teliti. Faktor penyebab kurangnya minat untuk menjadi akuntan profesional dan kuliah ada jurusan akuntansi dipaparkan oleh penelitian Allen (2004) yang menyatakan bahwa kurangnya minat individu untuk menjadi seorang akuntan profesional di Indonesia bisa 
dipengaruhi oleh minat dalam belajar akuntansi yang disebabkan oleh image mereka tentang akuntansi yang kurang baik. Sedikitnya peminat pada jurusan akuntansi dipengaruhi oleh persepsi mereka tentang akuntansi yang kurang baik.

Tetapi untuk sebagian orang, mereka berpersepsi bahwa akuntansi itu menyenangkan, berikut paparan yang mereka sampaikan:

$\begin{array}{lr}\text { "Mata } & \text { pelajaran } \\ \text { akuntansi } & \text { itu asyik } \\ \text { karena } & \text { berhubungan } \\ \text { dengan } & \text { keuangan } \\ \text { perusahaan } & \text { dan } \\ \text { keuangan pribadi dan } & \text { dan } \\ \text { prospek kerjanya luas, } \\ \text { kalau hitungannya gak } \\ \text { balance ngulang dari } \\ \text { awal makanya } \\ \text { menyenangkan.”[Hafidz, } \\ \text { siswa SMA kelas XII] }\end{array}$

Bagi mereka yang dari jurusan IPA, kemungkinan mereka juga bisa mengambil akuntansi dikarenakan mereka suka hitungan. Berikut paparan mereka:

"Pada saat datang ke bag pendaftaran lihat ada jurusan akuntansi dan waktu SMA IPA saya suka ngitung lebih dari pada hafalan, akhirnya saya pilih akuntansi.’[Ersyva, mahasiswa aktif tingkat akhir]

"Saya SMA IPA sedikit ada mapel akuntansi dan selama proses kuliah bisa ngikuti, menurut saya menyenangkan karena dari kecil suka dunia keuangan dan suka ngitung-

ngitungan.'[Safrida, mahasiswa aktif tingkat pertama]

Akuntansi itu sulit tetapi menyenangkan, siswa SMA mempunyai pendapat seperti itu, berikut paparan mereka:

"Belajar akuntansi itu
menyenangkan namun
kalau ketemu angka
yang tidak seharusnya
agak kecewa.
Menyenangkan karena
menghitung keuangan
serunya disitu dan
kesulitannya buat jurnal
angkanya harus sama
(balance)." [Anggi,
siswa SMA kelas XII]
"Menurut saya akuntansi
itu pelajarannya seru kita
perlu mencari tahu
walaupun susah karena
menghitung angka tapi
seru dan
menyenangkan."[Rizky,
siswa SMA kelas XII]

Bagi sebagian siswa SMA akuntansi itu sulit dikarenakan mereka berpersepsi karena banyak hitungan dan rumusnya. Anak SMA yang lebih suka hafalan tidak suka hitungan mereka tidak berminat mengambil jurusan akuntansi. Hal ini juga disampaikan oleh guru akuntansi, anak-anak menganggap akuntansi itu susah mata pelajarannya karena hanya menghitung angka dan tidak ada uangnya secara nyata.

Lain halnya dengan siswa SMA yang suka hitungan baik dari jurusan IPA maupun IPS, mereka berpersepsi bahwa akuntansi itu menyenangkan dan seru karena menghitung berhubungan dengan pengelolaan keuangan pribadi dan perusahaan, hal ini juga ditegaskan oleh guru akuntansi.

Sehingga peneliti memaknai bahwa niat dan alasan siswa SMA, calon pendaftar dan mahasiswa aktif untuk 
studi pada jurusan akuntansi dikarenakan sesuai dengan minat dan kemampuan mereka. Bagi mereka yang menyukai hitungan dan telah mendapatkan pengalaman mata pelajaran akuntansi selama SMA/SMK serta menurut mereka akuntansi itu menyenangkan dan dapat mengelola keuangan keuangan, kemungkinan mereka akan memilih untuk studi pada jurusan akuntansi. Berbeda halnya dengan mereka yang mempunyai alasan bahwa akuntansi itu rumit karena memang sebagian dari mereka lemah pada hitungan kuat pada teori dan kurang teliti, kemungkinan mereka memilih untuk tidak lanjut pada jurusan akuntansi.

\section{Niat dan Alasan untuk Berkarir pada Profesi Akuntan}

Profesi akuntan bagi sebagian orang menarik dan juga ada yang menyebutkan tidak menarik dan membosankan, tetapi ada juga yang menyampaikan bahwa profesi akuntan dan kuliah jurusan akuntansi itu menarik tetapi membosankan. Menurut siswa SMA kelas XII, profesi akuntan adalah menarik, berikut salah satu paparan yang disampaikan informan berikut ini:

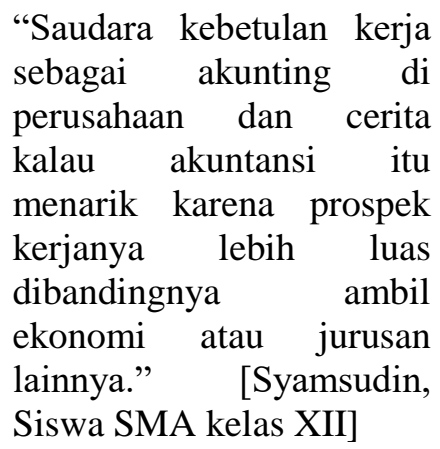

Bagi sebagian orang profesi akuntan itu membosankan, menurut data survey yang dilakukan oleh CNBC Indonesia menyatakan bahwa profesi akuntan merupakan salah satu profesi yang membosankan dari 10 profesi paling membosankan di dunia (berita CNBC Indonesia, 2018). Seperti halnya paparan yang disampaikan oleh salah satu informan berikut:

"Lebih suka kerja sendiri dan kalau kerja di kantor kurang berminat. Profesi akuntansi itu setiap hari pekerjaanya di balik meja dan itu itu aja yang dikerjakan dan membosankan dan orangnya introvert."

[Kelvin, mahasiswa aktif tingkat tengah]

Penelitian Uyar et al., (2011) menginvestigasi alasan penyebab mahasiswa memilih karir di akuntansi. Ada dua kategori temuan, yaitu mahasiswa ingin bekerja pada bidang akuntansi karena berasumsi bahwa dapat memperoleh pekerjaan yang terbaik dan sesuai dengan kemampuan dan minat mereka. Selanjutnya mahasiswa yang tidak ingin bekerja pada bidang akuntansi berasumsi bahwa akuntansi itu pekerjaan yang sedikit membuat stres, melelahkan dan membosankan. Salah satu informan berikut ini, dia menyebutkan bahwa profesi akuntan itu menarik tetapi dia mempunyai alasan lain karena tidak berencana berprofesi sebagai akuntan karena bagi dia profesi akuntan itu membosankan, berikut paparan yang disampaikan:

"Akuntan itu pekerjaan
yang menarik apalagi
auditor menggiurkan
sekali imbalannya, tetapi
saya kurang tertarik
menjadi accounting dan
saya tertarik ke bisnis dan
broadcasting. Menurut
saya Akuntansi itu sulit
dan
membosankan."[Nerisa,
Mahasiswa aktif tingkat
tengah]

Dengan demikian peneliti memaknai bahwa niat dan alasan mereka untuk berkarir pada profesi akuntan 
adalah karena menurut mereka profesi akuntan itu prospek kedepannya dan gajinya tinggi. Berbeda halnya dengan niat dan alasan mereka untuk tidak berkarir pada profesi akuntan karena mereka lebih memilih untuk membuka usaha sendiri dan menurut mereka profesi akuntan itu pekerjaannya sulit dan membosankan.

\section{Persepsi Masyarakat Terhadap Profesi Akuntansi}

Profesi bidang akuntansi adalah salah satu profesi yang keren dan membanggakan. Semua jenis bisnis dan entitas termasuk sebuah negara, membutuhkan orang yang ahli dalam bidang akuntansi keuangan. Seperti halnya yang disampaikan salah satu informan sebagai berikut:

"Dosen kami cerita
katanya konsultan pajak
eksternal ilmunya
banyak dan orangnya
keren dan gajinya
banyak serta pengennya
ambil profesi sesuai
dengan ilmu yang saya
pelajari dan menurut
saya profesi akuntan
bergengsi
(prestige)."[Ersyva,
mahasiswa aktif tingkat
akhir]

Selain prestige, gaji tinggi juga mempengaruhi seseorang untuk berprofesi sebagai akuntan, berikut paparan yang disampaikan oleh salah satu informan berikut ini:

"Katanya mama kalau pengen gaji yang besar ambil bidang studi ekonomi atau akuntansi dan setelah masuk minatnya di audit.”[Melisa, mahasiswa tingkat pertama]
Di sisi lainnya, menurut mahasiswa non akuntansi bahwa profesi dan kuliah di jurusan akuntansi itu kurang prospek kedepannya, berikut disampaikan oleh informan berikut ini:

"papa saya bilang dinda

kalau ambil jurusan

ambil jurusan yang bisa

menunjang untuk 10

tahun kedepan dan

apalagi sekarang kan

jamannya

teknologi.'[Dinda,

mahasiswa non

akuntansi]

"Tidak dibolehin imasuk

akuntansi karena

misalnya kerjanya di

perbankan resikonya

lebih tinggi misalanya

ada selisih dan jurusan

sistem informasi

resikonya lebih

kecil.'[Sasha,

mahasiswa non

akuntansi]

Akan tetapi bagi sebagian orang mereka berpersepsi bahwa profesi akuntan kurang menantang jika dibandingkan menjadi seorang entrepenuer, berikut paparan yang disampaikan oleh informan berikut ini:

"Setelah lulus saya ingin membuka usaha perikanan yang bisa dan tahu tentang accounting untuk mengatasi resiko kegagalan selain itu menurut saya accounting kurang menantang beda kalau punya usaha tantangannya

banyak.'[Dwi Surya, mahasiswa aktif tingkat pertama] 
Terkait dengan faktor instrinsik dan ekstrinsik yang mempegaruhi seseorang dalam menentukan karir di bidang akuntansi hasil temuan lapangan sejalan dengan penelitian yang dilakukan oleh Hsiao and Nova (2016) dan Ng et al., (2017) hasil penelitian mereka menyatakan bahwa memilih akuntan sebagai karir karena dipengaruhi oleh beberapa faktor seperti kreativitas, kebebasan, lingkungan yang berubah dan dinamis, kerja yang aman, memperoleh uang, lapangan pekerjaan tersedia, dan karena pengaruh orang lain seperti teman dan guru serta dipengaruhi oleh faktor intrinsik dan ekstrinsik. Penelitian Malthus dan Flower (2009) juga menambahkan bahwa sebagain orang berpersepsi bahwa profesi akuntan kurang menantang (kurang memberikan kepuasan) hal ini disebut faktor instrinsik dan sebagian mereka tertarik pada profesi akuntan karena profesi akuntan memiliki prestige, bergaji tinggi (faktor ekstrinsik).

Sehingga peneliti memaknai bahwa persepsi masyarakat tentang profesi akuntan bahwa profesi akuntan menjanjikan dilihat dari profesi akuntan yang tidak hanya mendapatkan gaji yang besar tetapi juga karena menurut arahan dari guru SMA bahwa profesi akuntan kedepannya pasti dibutuhkan perusahaan. Akuntansi membanggakan dilihat dari profesi akuntan, menurut mahasiswa profesi akuntan bergengsi yang merupakan faktor ekstrinsik, tidak hanya bisa mendapatkan pekerjaan yang sesuai dengan bidang dan kemampuannya serta gaji yang tinggi. Berbeda halnya masyarakat yang berpersepsi negatif karena menurut mereka profesi akuntan tidak menjanjikan dilihat dari kepercayaan dari pengalaman orang terdekat mereka menyatakan bahwa profesi akuntansi kurang prospek dan pekerjaannya beresiko tinggi serta dari faktor instrinsik profesi akuntan kurang menantang jika dibandingkan dengan membuka usaha sendiri.

\section{Persepsi Guru dan Orang Tua Tentang Akuntansi Sebagai Karir}

Profesi dari lulusan jurusan akuntansi sendiri dinilai banyak memiliki peluang untuk bekerja di sebuah perusahaan bonafit (berita www.liputan6.com, 15 Januari 2019 12.35 Wib Hal 3). Hal ini seperti yang dipaparkan oleh salah satu informan guru akuntansi SMA berikut ini:

"Kita harus bisa
memotivasi anak-anak
bahwa akuntansi itu
lebih menarik untuk
peluang kerjanya lebih
bagus dan menjanjikan."
[Cahya, guru akuntansi
SMA]

Pernyataan di atas juga dikuatkan oleh guru bimbingan karir SMA dan orang tua siswa, berikut paparan yang disampaikan:

"Kalau menurut saya peluang kerjanya bagus dan kedepannya menjanjikan, terus terang saja saya punya hubungan baik dengan ortu siswa ortunya akuntan. Kenal baik dengan beliauanya ternyata kalau benarbenar jadi akuntan profesional itu dibutuhkan dimana aja, beliauanya adalah seorang auditor. Dari situ saya bisa membayangkan kalau benar-benar orang lapangan pasti banyak dibutuhkan perusahaan." [Erika, guru BK SMA]

"Katanya mama kalau pengen gaji yang besar 


$\begin{array}{lr}\text { ambil bidang } & \text { studi } \\ \text { ekonomi atau } & \text { akuntansi } \\ \text { dan setelah } & \text { masuk } \\ \text { minatnya } & \text { di } \\ \text { audit.'[Melisa, } & \\ \text { mahasiswa } & \text { tingkat } \\ \text { pertama] } & \end{array}$

Di sisi lainnya, menurut mahasiswa non akuntansi bahwa profesi dan kuliah di jurusan akuntansi itu kurang prospek kedepannya, berikut disampaikan oleh informan berikut ini:

"papa saya bilang dinda
kalau ambil jurusan
ambil jurusan yang bisa
menunjang untuk 10
tahun kedepan dan
apalagi sekarang kan
jamannya
teknologi."[Dinda,
mahasiswa
akuntansi] non
"Tidak dibolehin masuk
akuntansi karena
misalnya kerjanya di
perbankan resikonya
lebih tinggi misalnya ada
selisih dan jurusan
sistem informasi
resikonya lebih
kecil."[Sasha, non
mahasiswa
akuntansi]

Sehingga peneliti memaknai bahwa guru dan orang tua dalam hal ini termasuk dari bagian masyarakat yang mempunyai persepsi positif terhadap profesi akuntan yang menyatakan bahwa berkarir pada profesi akuntan adalah merupakan pilihan karir yang tepat tidak hanya memperoleh gaji yang tinggi dan profesinya menjajikan tetapi juga profesinya lebih bagus dibandingkan dengan profesi lainnya. Sama halnya dengan mereka yang merupakan bagian dari masyarakat yang berpersepsi negatif tentang memlilih karir pada akuntansi, mereka berpersepsi bahwa akuntansi itu pekerjaanya yang beresiko besar dan kurang prospek kedepannya dibanding dengan karir lainnya.

\section{Persepsi Guru dan Orang Tua dalam Mempengaruhi dan Mempromosikann Akuntansi Sebagai Subyek Studi dan Karir}

Minat melanjutkan studi ke perguruan tinggi dengan jurusan tertentu, khususnya pada jurusan akuntansi salah satu faktor yang mendorong para calon pendaftar karena dorongan dari orangorang disekitarnya, seperti karena orang tua, teman, guru akuntansi atau guru penasehat karir, dan lain sebagainya. Pertama adalah dukungan dari guru akuntansi seperti yang telah disampaikan oleh Mauldin et al., (2000) hasilnya adalah bahwa guru akuntansi memainkan peranan penting dan berpengaruh secara signifikan terhadap keputusan mahasiswa untuk melanjutkan studi pada jurusan akuntansi.

Adapun dari hasil wawancara dan Fokus Group Discussion telah di paparkan oleh salah satu informan siswa SMA adalah sebagai berikut:

"Dari guru akuntansi waktu mengajar di kelas memberikan arahan bagi yang berminat dan suka hitungan dan mempunyai kemampuan yang cukup bisa melanjutkan di jurusan akuntansi setelah ini. Bisa ambil di PTN dan PTS menurut pilihan anak-anak"[Biyan, siswa SMA]

Ketika guru akuntansi dikonfirmasi terkait menyarankan anak-anak siswa kelas XII untuk lanjut studi ke jurusan akuntansi salah satu guru menjawab demikian: 
"Pertama memang saya menganjurkan melihat hasil psikotest, anak anak kan punya bakat dan minatnya dan yang kedua saya lihat nilainilainya dulu, kalau nilai ekonomi/akuntansi unggul maka bisa lanjut ke universitas di jurusan akuntansi. Saya selalu mengajurkan seperti itu, mau gak mau untuk support anak-anak ambil jurusan akuntansi. Cara belajar mereka males di sekolah ini, satu kelas dapat 5 anak yang mau belajar akuntansi saja sudah alhamdulillah dan pasti bisa masuk jurusan akuntansi, yang jadi unggulan saya. Percuma saja kalian jurusan IPS kalau tidak mau ambil ekonomi/akuntansi, masak tidak mau menggantikan sri mulyani minimal jadi guru akuntansi." [Cahya, Guru akuntansi SMA]

Kedua yang berpengaruh adalah guru BK di sekolah, penelitian terdahulu yang dilakukan oleh Saputra (2017) hasil penelitian menunjukkan bahwa pelaksanaan penanaman minat oleh guru konseling dengan memperlihatkan contoh minat dan menyediakan kesempatan bagi siswa untuk menunjukkan minatnya dan menurut hasil penelitian Sutrisno (2017) menyebutkan bahwa layanan informasi studi lanjut berpengaruh terhadap minat siswa masuk perguruan tinggi. Oleh karena itu dapat dimanfaatkan sebagai bahan masukan dan pertimbangan bagi Guru Bimbingan dan Konseling agar dapat meningkatkan perannya dalam mengarahkan siswa-siswa SMA yang bermaksud melanjutkan ke perguruan tinggi setelah selesai studi. Akan tetapi hasil penelitian Flower dan Malthus (2009) bertolak belakang karena guru penasihat karir berpersepsi negatif dengan menyatakan bahwa profesi akuntan kurang bergengsi dibanding dengan profesi lain, misalnya dosen, lawyer dan dokter dan profesi akuntan adalah pilihan karir terakhir. Dari informan yang diwawancarai memaparkan perihal sebagai berikut:

"Mereka datang ke saya
masih bingung antara
akuntansi r dan
manajemen r itu
bagaimana. rita
kembalikan ke anaknya
dan kalau anaknya
bingung baru kami gali
lebih dalam melalui
konsultasi. Di BK selalu
ada konseling kalau
kelas XII langsung
konsultasi ke BK.
"[Erika, Guru BK]

Guru BK dikonfirmasi tentang menyarankan siswanya ke jurusan akuntansi dan siswa juga ditanya tentang peran BK untuk konsultasi dan menentukan pilihan mereka pada jurusan akuntansi semuanya memaparkan bahwa guru BK mempunyai pengaruh dalam menentukan keberhasilan mereka melalui konseling di sekolah. Guru BK memberikan wawasan kepada siswa tentang profesi akuntan, berikut paparan yang mereka sampaikan:

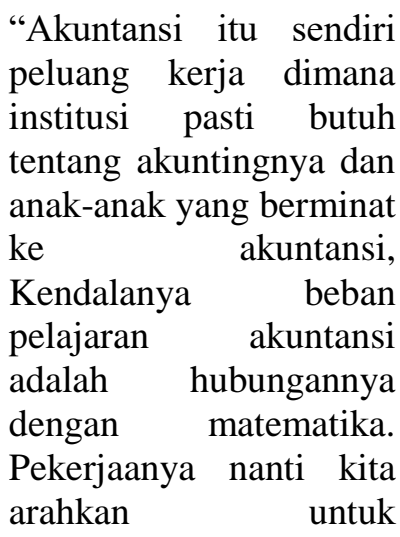


pekerjaannya ke bisnis

dan

akuntansinya."[Ermi, guru BK]

Selanjutnya yang ketiga adalah orang tua, menurut penelitian terdahulu yang disampaikan oleh Damarjati (2017) menyampaikan bahwa tingkat pendapatan orang tua berpengaruh positif terhadap minat siswa melanjutkan studi ke perguruan tinggi. Prestasi belajar, motivasi belajar dan status sosial ekonomi orang tua berpengaruh positif terhadap minat siswa untuk melanjutkan studi ke perguruan tinggi (Rahayu, 2013). Menentukan pilihan untuk masa depan anaknya tidak hanya ditentukan oleh kemampuan anaknya sendiri tetapi juga kemampuan orang tua seperti yang dipaparkan oleh beberapa informan berikut ini:

"Kami biasanya
mengembalikan lagi
kepada siswa minatnya
kemana dan pastinya
atas persetujuan ortu.
Kadang
anaknya dan ortu beda.
Kami arahkan dari
nilainya bagusnya
dimana, passionnya
kemampuan anaknya."
[Erika, Guru BK]

Selain karena kemampuan anak dan orang tuanya, para orang tua menyarankan anaknya untuk studi pada jurusan akuntansi dikarenakan rata-rata orang tua atau keluarga mereka ada yang bekerja sebagai accounting atau pajak di perusahaan dan meminta anaknya untuk ngikuti jejak mereka menurut mereka akuntansi dianggap karir yang bagus di masa depan dengan gaji yang tinggi dan prospek kerjanya yang luas. Penelitian sebelumnya yang disampaikan oleh Yudhantoko (2013) menunjukkan bahwa semua faktor - faktor yang diteliti seperti penghargaan finansial, pendidik profesional, pengakuan profesional, nilai - nilai sosial, lingkungan kerja, pertimbangan pasar kerja, keluarga dan teman, instruktur akuntansi, rekan, serta personalitas adalah merupakan faktor yang menarik minat mahasiswa akuntansi pada profesi akuntan manajemen. Seperti yang dipaparkan oleh beberapa siswa SMA berikut ini:

"Prospek kerjanya luas dan ada dorongan dari ortu dan mama kerjanya di bagian keuangan pajak di PT Alkonusa.'[Rizky, Siswa SMA]“

Rencana mengambil akuntansi karena murni dari diri sendiri. Terinspirasi dari ibu saya menghitung cepat dan isaya seorang kasir restoran."[Eriko, siswa SMA]

"Yang menyarankan ke akuntansi karena papa, karena papa konsultan pajak buka praktek sendiri di rumah, pengennya papa diikuti jejak anaknya.’[Leofani, mahasiswa aktif tingkat akhir]

Terakhir adalah pengaruh teman, selain orang tua dan guru di sekolah lingkungan teman juga mempengaruhi siswa mengambil jurusan akuntansi. Berdasarkan penelitian sebelumnya yang dilakukan oleh Hsiao dan Nova (2016) adanya pengaruh teman dan guru terhadap penentuan berkarir pada bidang akuntansi. Hasil penelitian sebelumnya yang sama juga disampaikan oleh Budiarti (2015) menyebutkan bahwa ada pengaruh lingkungan teman sebaya, kondisi sosial ekonomi orang tua, dan peran guru terhadap minat melanjutkan studi ke perguruan tinggi siswa kelas XII 
jurusan Administrasi Perkantoran di SMK Negeri 2 Semarang tahun ajaran 2014/2015 secara simultan maupun secara parsial. Dari hasil paparan beberapa informan menyebutkan bahwa:

"Berminat ke akuntansi selain dari dirinya sendiri, biasanya anakanak ada yang ikut teman. Ortu kalah sama temannya. Contoh ada yang minta formulir kampus A, kenapa kok tidak kemaren-kemaren? Karena teman saya daftar kekampus ini bu. Kalau masalah kampusnya tergantung pilihan jurusan anaknya.'[Erika, Guru BK]

Sehingga peneliti memaknai bahwa guru akuntansi mempunyai peran dalam mempengaruhi dan mempromosikan siswa SMA untuk mengambil jurusan akuntansi, guru akuntansi mengarahkan siswa berdasarkan bakat minat dan kemampuan mereka. Siswa SMA yang berminat mengambil jurusan akuntansi melakukan konsultasi ke guru BK. Guru BK mengarahkan siswa tidak hanya berdasarkan minat dan kemampuan mereka tetapi juga berdasarkan kemampuan orang tua. Pengaruh orang tua dalam menentukan studi pada jurusan akuntansi untuk putera-puteri mereka tidak hanya didasarkan pada pengalaman orang tua yang telah bekerja pada bidang akuntansi tetapi juga karena orang tua mempunyai informasi dan image yang bagus tentang jurusan akuntansi Stikom Surabaya. Teman juga berpengaruh terhadap pemilihan jurusan akuntansi, selain dari kemampuan mereka sendiri. Mereka berpersepsi dengan adanya teman meneruskan studi pada jurusan di kampus yang sama karena merasa mudah beradaptasi pada lingkungan yang baru dengan adanya teman yang sudah mereka kenal sebelumnya.

\section{Faktor Lain}

Beberapa faktor lainnya yang juga ditemukan selama fokus grup diskusi dan wawancara yang berkaitan dengan persepsi studi pada jurusan akuntansi dan profesi akuntan. Berikut faktor lainnya dijabarkan dalam beberapa sub judul sebagai berikut:

\subsection{Pelajaran Akuntansi di SMA}

Pelajaran akuntansi di SMA diberikan pada kelas XI dan XII, dan namanya adalah mata pelajaran ekonomi yang didalamnya selain diajarkan tentang ilmu ekonomi juga diajarkan tentang ilmu akuntansi. Kurikulumnya dijadikan satu di akhir semester bergantian. Berikut yang dipaparkan oleh guru ekonomi SMA berikut ini:

"Mata pelajaran
akuntansi digabung jadi
satu dengan mata
pelajaran ekonomi.
Untuk mata pelajarannya
tengah semester
ekonomi dan tengah
semester akuntansi. Jadi
tidak ada mata pelajaran
khusus untuk akuntansi.
Dan anak-anak dapat
mata pelajarannya di
kelas XI dan XII.
Mungkin beda ya kalau
di SMK dapat mata
pelajaran akuntansi
sendiri tidak digabung
dengan ekonomi dan
tentunya mereka dapat
pelajarannya lebih
banyak"[Arum, guru
ekonomi SMA]

Penggabungan antara ilmu ekonomi dan ilmu akuntansi hal ini dapat menyebakan tersebarnya pilihan anakanak terkait studi pada bidang ekonomi atau akuntansi. Data penelusuran bakat minat untuk jurusan favorit SMA Hangtuah 2 Sidoarjo Tahun 2018 menunjukkan bahwa minat siswa pada bidang soshum tersebar khusus pada jurusan akuntansi ada 19 orang dengan 
jumlah prosentase $8 \%$, jurusan akuntansi menduduki posisi peringkat ke 5 dari keseluruhan jurusan soshum yang diminati siswa SMA Hangtuah 2 Sidoarjo, sedangkan untuk jurusan ekonomi yang termasuk bidang ekonomi manajemen bisnis, ekonomi pembangunan dan ilmu ekonomi paling banyak peminatnya jika dibanding dengan jurusan akuntansi yaitu sebesar 56 siswa dengan jumlah prosentase 23,43\%. Hal ini menunjukkan bahwa peminat jurusan akuntansi masih sedikit jika dibanding dengan jurusan ekonomi.

Selain itu siswa SMA tidak memilih akuntansi karena menurut mereka akuntansi banyak ngitungnya dan sulit tidak seperti jurusan ekonomi. Seperti yang dipaparkan oleh salah satu informan berikut ini:

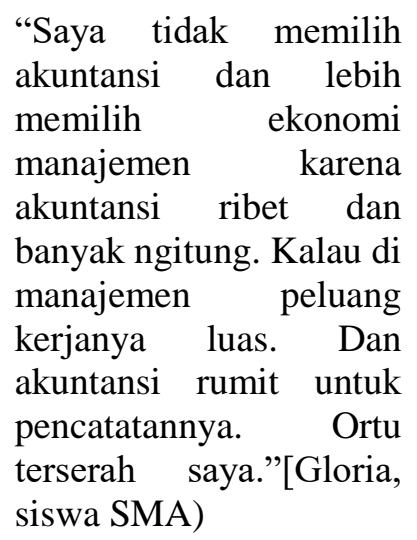

Sehingga peneliti memaknai bahwa mata pelajaran akuntansi di SMA yang diterima siswa terbatas karena kurikulumnya digabung dengan mata pelajaran ekonomi, hal ini menyebabkan ilmu akuntansi yang diterima siswa SMA hanya sedikit. Hal ini juga diperkuat oleh pemetaan bakat dan minat siswa serta hasil wawancara kepada siswa SMA menunjukkan bahwa jurusan akuntansi peminatnya tidak sebanyak jurusan ekonomi manajemen dan siswa SMA mempersepsikan bahwa jurusan ekonomi manajemen hitungannya tidak seribet akuntansi, siswa yang tidak seberapa kuat dihitungan, mereka cenderung untuk memilih jurusan ekonomi dibanding dengan jurusan akuntansi.

\subsection{Citra (Image) Stikom}

Mengubah image sebuah perguruan tinggi tidaklah mudah, jika salah satu kampus tersebut sudah terbranding dengan salah satu label maka sebuah proses panjang yang harus dilakukan untuk mengubah image tersebut. Hal ini yang tengah dihadapi oleh Stikom Surabaya, dari mulai berdiri hingga saat ini Stikom Surabaya masih berlabel sebagai kampus IT. Menurut beberapa informan yang diwawancarai juga menyampaikan bahwa imagenya masih kampus IT, untuk fakultas ekonomi bisnis yang di dalamnya ada jurusan akuntansi tidak tahu sama sekali. Seperti halnya yang disampaikan oleh beberapa informan siswa SMA kelas XII berikut ini:
"Imagenya tahunya stikom kampus IT dan menurut saya jurusan akuntansi baru."'[Safrizal, Siswa SMA]
"Tidak tahu kalau stikom ada jurusan akuntansi, baru tahu ini tadi. Pada saat presentasi juga belum tahu. Keluarga juga belum tahu."'AAffan, Siswa SMA]

Mahasiswa aktif jurusan akuntansi Stikom Surabaya mempunyai pengalaman yang sama, pada saat mereka mendaftar rata-rata mereka tidak mengetahui kalau di Stikom ada jurusan akuntansi, setelah mereka datang ke counter pendaftaran dan mendapat brosur serta browsing di website Stikom Surabaya akhirnya mereka baru tahu kalau di Stikom ada jurusan akuntansi, kalau pun mereka mengetahuinya pasti menyebutnya akuntansi adalah prodi baru di kampus Stikom Surabaya adapun paparan yang disampaikan adalah sebagai berikut: 


\section{"Imagenya Stikom}

Surabaya adalah kampus IT dan tahunya ada jurusan akuntansi pas kesini." [Leofani, mahasiswa aktif tingkat akhir]

Ketidaktahuan tentang jurusan akuntansi Stikom Surabaya juga dipaparkan oleh guru akuntansi yang mengajar di kelas, berikut paparan yang disampaikan:

$\begin{array}{lr}\text { "Saya baru denger } & \text { den } \\ \text { sekarang ini kalau stikom } \\ \text { ada jurusan akuntansi. } \\ \text { Sebelumnya masih belum } \\ \text { tahu. Setahu saya stikom } \\ \text { itukuliah } & \text { jurusan } \\ \text { komputer. Punya teman } \\ \text { anaknya kuliah ambil } \\ \text { jurusan komputer di } \\ \text { stikom. Imagenya stikom } \\ \text { informatika } \\ \text { computer."[Arum, guru } \\ \text { Akuntansi] }\end{array}$

Upaya branding harus konsisten dilaksanakan dengan melakukan iklan di media massa dan elektronik, intens melakukan kegiatan kampus sebagai upaya pengenalan kampus di berbagai sekolah dan masyarakat umum disamping tetap intens melakukan kegiatan rutin expo campus dan presentasi. Dari data isian sumber informasi yang direcord calon mahasiswa yang mendaftar jurusan akuntansi di Stikom Surabaya selama tahun 2015 sampai dengan tahun 2018 menunjukkan bahwa mereka memilih jurusan akuntansi dan mengetahui Stikom Surabaya dari beberapa sumber.

Rekap data isian sumber informasi menunjukkan bahwa keluarga adalah yang berperan memberikan informasi paling besar terhadap calon mahasiswa mengambil jurusan akuntansi Stikom Surabaya. Dapat diartikan bahwa sumber informasi yang paling berpengaruh adalah kelurga yaitu sebesar $30 \%$, keluarga dalam hal ini adalah orang tua alumni Stikom Surabaya, orang tua yang berprofesi sebagai accounting, saudara mahasiswa yang kuliah atau alumni Stikom Surabaya, saudara yang berkarir di bidang akuntansi. Selanjutnya disusul oleh teman dan internet sebesar 19\% juga berpotensi dalam menarik minat masyarakat untuk melanjutkan studi di Stikom Surabaya. Sedangkan sisanya diperoleh dari sumber lainnya sebesar $32 \%$ yaitu iklan di surat kabar, presentasi, expo, guru, brosur dan kunjungan ke Stikom Surabaya.

Sehingga peneliti memaknai bahwa Citra (Image) Stikom Surabaya masih melekat di benak masyarakat bahwa kampus yang hanya mempunyai jurusan informatika, teknik, desain. Ketidaktahuan masyarakat akan jurusan baru yaitu ekonomi dan bisnis khususnya akuntansi hal ini menyebabkan persepsi mereka tentang jurusan akuntansi adalah prodi baru sehingga masyarakat enggan memilih akuntansi Stikom Surabaya.

\subsection{Pengaruh Perguruan Tinggi}

Pertimbangan memilih sebuah perguruan tinggi ada beberapa faktor yaitu terkait dengan produk atau jasa yang diberikan, biaya studi, lokasi, fasilitas, beasiswa dan akreditasi.

Biaya pendidikan yang tinggi dapat menyebabkan seseorang untuk tidak jadi melanjutkan studi pada suatu perguruan tinggi tertentu dan lebih memilih untuk masuk jurusan atau perguruan tinggi lainnya atau tidak meneruskan. Akan tetapi biaya itu relatif tergantung dari fasilitas yang didapatkan. Berikut paparan yang disampaikan oleh informan berikut ini:

"Biaya kuliah di stikom sangat mahal kalau dibanding univ lainnya, Tapi sebanding antara biaya dan falisilitasnya" [Safrida, 
Mahasiswa aktif tingkat pertama]

Selain hasil temuan lapangan diperoleh juga informasi dari hasil data follow up via telepon kepada calon mahasiswa Stikom Surabaya yang tidak jadi melanjutkan studi pada jurusan akuntansi. Dari rekap data follow up via telp menunjukkan bahwa menunjukkan bahwa faktor terbesar yang menyebabkan calon pendaftar tidak jadi memilih Stikom Surabaya karena faktor biaya yaitu sebesar $34 \%$ dan peran orang tua sebesar $26 \%$. Sedangkan faktor lainnya sebesar $32 \%$ mempengaruhi calon mahasiswa memilih kampus lain yang bisa saja disebabkan oleh jarak, akreditasi, referensi saudara atau karena pertimbangan jurusan yang mereka minati ada di kampus lainnya.

Fasilitas yang diperoleh mahasiswa Stikom Surabaya menurut mereka sebanding dengan yang mereka dapakan bahkan mereka memaparkan dapatnya lebih banyak jika dibandingkan dengan kampus lain, seperti yang disampaikan oleh salah satu informan berikut:

"Setelah saya tahu ternyata dapat banyak selama kuliah karena dapat coding sistem informasi dan dapat akuntansinya dengan biaya seminimminimnya, kalau dari segi fasilitas sudah memenuhi dan dari segi biaya cukup terjangkau dibanding dengan kampus lainnya." [Pratiwi, Mahasiswa aktif tingkat akhir]

Lokasi perguruan tinggi juga menjadi salah faktor yang dipertimbangkan untuk memilih kampus sebagai tempat melanjutkan studi. Akan tetapi jauh dekatnya lokasi kampus tidak terlalu berpengaruh terhadap memilih tempat studi. Seperti yang dipaparkan oleh informan berikut ini:

\begin{tabular}{l}
\multicolumn{3}{c}{ "Imagenya kampus } \\
IT dan tahunya ada \\
jurusan akuntansi pas \\
kesini. Lokasi rumah ke \\
kampus Stikom juga \\
dekat juga jadi \\
pertimbangan kenapa \\
ngambil di Stikom \\
Surabaya." [Leofani, \\
Mahasiswa aktif tingkat \\
akhir]
\end{tabular}

Ketersediaan bantuan keuangan pada suatu perguruan tinggi juga menentukan seseorang memutuskan memilih perguruan tinggi tersebut, seperti halnya yang dipaparkan oleh salah satu informan berikut:

"Saya hanya ngasih informasi kalau Stikom ada jurusan akuntansi dan bisa dapat beasiswa dan anaknya tidak daftar di kampus lain dan hanya daftar di stikom" [Tarto, Orang tua mahasiswa]

Rencana studi siswa SMA kelas XII yang menyatakan minat dan mengambil jurusan akuntansi, ternyata setelah ditanya lebih dalam apakah berencana untuk melanjutkan di Stikom Surabaya. Sebagian besar mereka mereka masih belum tahu dan tidak berminat ke Stikom Surabaya, mereka menyampaikan orientasi ke PTN terlebih dahulu setelah itu pilihan keduanya lebih memilih ke PTS lain bukan Stikom Surabaya. Berikut paparan yang disampaikan mereka:

"Saudara juga ada yang dari universitas XYZ dan masih bingung PTS nya masih pilih yang mana. Imagenya tahunya 
stikom kampus IT dan menurut saya jurusan akuntansi baru. "Saya rencananya ke PTN, coba kedinasan, PTS kata bapak saya universitas DEF katanya akreditasinya "A" tahu dari presentasi kelas. Jarak dari rumah deket. Ada saudara saya alumni sana."[Safrizal, Siswa SMA]

Paparan yang telah disampaikan beberapa informan masih enggan dan belum memilih jurusan akuntansi di Stikom Surabaya persepsi mereka jurusan akuntansi Stikom Surabaya masih baru dan imagenya adalah kampus IT (belajar komunikasi dan komputer). Hasil wawancara dan fokus grup diskusi dalam penelitian ini sejalan dengan temuan penelitian yang dilakukan oleh Kusuma (2016), Suryani dan Ginting (2013) dan Handayani (2017) menyatakan bahwa faktor perguruan tinggi dengan variabel lokasi, reputasi perguruan tinggi, fasilitas pendidikan, program akademik, promosi, biaya pendidikan, ketersediaan bantuan keuangan, produk, tempat, orang, bukti fisik dan proses.

Sehingga peneliti memaknai bahwa biaya studi yang mahal, fasilitas yang memadahi, lokasi kampus, ketersediaan beasiswa, jurusan akuntansi yang baru dan akreditasi, pengalaman orang terdekat mereka yang kuliah pada suatu perguruan tinggi mempengaruhi mereka dalam memilih jurusan akuntansi Stikom Surabaya.

\section{Simpulan dan Saran Simpulan}

Penelitian ini menghasilkan persepsi yang berbeda beda, akan tetapi sebagian besar informan menyatakan persepsi negatif tentang akuntansi. Masyarakat berpersepsi negatif tentang kuliah dan berprofesi akuntan dikarenakan mempunyai alasan bahwa akuntansi itu rumit/sulit dan bagi mereka yang lemah pada hitungan dan kurang teliti kemungkinan mereka tidak akan berkarir sebagai akuntan mereka lebih memilih untuk berbisnis. Tetapi berbeda halnya dengan masyarakat yang berpersepsi positif tentang akuntansi, mereka menyatakan untuk lanjut studi dan berprofesi akuntan karena sesuai dengan minat dan kemampuan mereka yang menyukai hitungan dan profesi akuntan memiliki gaji tinggi serta prospek untuk kedepannya.

Sama halnya dengan peran serta orang - orang sekitar seperti guru dan orang tua dalam mempengaruhi dan mempromosikan akuntansi sebagai subyek studi dan karir, mereka juga berpersepsi positif dan negatif. Sebagian besar para orang tua dan guru berpersepsi postif tentang akuntansi, hal ini dikarenakan berdasarkan pengalaman mereka pada bidang yang sama dan kepercayaan dari orang terdekat mereka bahwa profesi akuntan itu pasti dibutuhkan selain memperoleh gaji tinggi dan prosfesinya lebih menjajikan dibandingkan dengan profesi lainnya. Persepsi negatif dikarenakan mereka menyatakan bahwa profesi akuntan beresiko besar dan kurang prospek jika dibandingkan dnegan profesi lainnya. Selain guru dan orang tua juga ditemukan dalam penelitian ini bahwa teman juga berpengaruh dalam menentukan pilihan studi pada jurusan akuntansi.

Faktor lainnya ditemukan dalam penelitian ini, yaitu mata pelajaran akuntansi yang diterima siswa di SMA terbatas sehingga siswa SMA mempersepsikan bahwa mata pelajaran akuntansi itu sulit. Selain itu juga ditemukan image kampus Stikom Surabaya menimbulkan persepsi yang masih menganggap hanya kampus yang memiliki jurusan teknologi informasi dan desain, banyak yang belum tahu ada prodi akuntansi. Terakhir, biaya studi yang mahal, fasilitas, lokasi kampus, beasiswa, prodi baru dan akreditasi membuat persepsi masyarakat negatif 
dan mencari alternatif kampus lain ketika hendak menyekolahkan anaknya untuk studi di kampus Stikom Surabaya dan pengalaman orang terdekat mereka mempengaruhi dalam melanjutkan studi pada jurusan akuntansi Stikom Surabaya.

Hasil penelitian ini membawa beberapa implikasi sebagai berikut:

1. Siswa SMA mengenal akuntansi dengan waktu yang singkat dan terbatas sehingga mereka tidak dapat memahami akuntansi dengan baik, hal ini memberikan implikasi bahwa sebaiknya mata pelajaran akuntansi di SMA diberikan mulai kelas $\mathrm{X}$ sampai dengan kelas XII tanpa adanya penggabungan dengan mata pelajaran ekonomi.

2. Persepsi negatif tentang profesi akuntan sehingga mereka tidak berminat berprofesi sebagai seorang akuntan, hal ini memberikan implikasi bahwa asosiasi profesi akuntan hendaknya dapat meningkatkan sosialiasi dengan cara mengadakan program-program baru yang ditujukan kepada siswa SMA dan mahasiswa untuk meningkatkan minat mereka terhadap profesi akuntan.

3. Implementasi Young Role Model generasi $\mathrm{Z}$, generasi $\mathrm{Z}$ tidak peduli dengan profesi akuntan dan mereka ingin membuka bisnis sendiri. Hal ini memberikan implikasi bahwa Asosiasi profesi akuntan hendaknya mengimplementasikan Young Role Model untuk memperkenalkan dan mempromosikan profesi akuntan kepada masyarakat dengan menggambarkan profesi akuntan sebagai anak muda yang profesional dan menekuni bidang bisnis. Inovasi metode pembelajaran akuntansi di SMA dan Stikom Surabaya dengan menggunakan collaborative learning yang dapat menjadikan siswa lebih produktif, kreatif dan afektif.
4. Biaya yang mahal, lokasi kampus, ketersediaan beasiswa, jurusan akuntansi yang baru dan akreditasi, pengalaman orang terdekat mereka yang kuliah pada suatu perguruan tinggi mempengaruhi mereka dalam memilih jurusan akuntansi Stikom Surabaya, hal ini dapat memberikan implikasi bahwa terkait fasilitas, prestasi dan akreditasi Stikom Surabaya hendaknya dilakukan upaya peningkatan secara berkelanjutan, sedangkan biaya studi jurusan akuntansi dapat dievaluasi kembali pada tahun ajaran berikutnya agar dapat menarik calon mahasiswa.

5. Keluarga, teman, internet dan surat kabar merupakan sumber informasi tertinggi orang memperoleh informasi dan memilih jurusan akuntansi Stikom Surabaya, hal ini memberikan implikasi bahwa selain lebih mengoptimalkan iklan dan memblow up kegiatan jurusan akuntansi melalui media internet, sumber informasi dari keluarga, teman dan dari kegiatan promosi rutin lainnya (seminar, workshop, lomba, iklan di media massa dan elektronik, pameran dan presentasi ke SMA) hendaknya ditingkatkan bagian marketing Stikom Surabaya untuk dapat meningkatkan jumlah mahasiswa.

\section{Saran}

Penelitian ini memiliki keterbatasan yang diharapkan dapat dikembangkan pada penelitian di masa yang akan datang adalah:

1. Tempat dilakukannya FGD dan wawancara dalam penelitian ini di dalam tempat penelitian hal ini kemungkinan mendapatkan hasil yang kurang sesuai dengan yang diharapkan, informan cenderung takut untuk mengungkap semua informasi dan informasi yang disampaikan cenderung pada halhal umum, hal ini disebabkan 
karena sulitnya mengumpulkan semua informan di satu tempat dalam waktu yang bersamaan.

2. Informan dalam penelitian ini terbatas pada siswa SMA, calon pendaftar, guru SMA, mahasiswa aktif, dan orang tua, sementara orang lain yang dapat mempengaruhi mereka untuk lanjut studi pada jurusan akuntansi dan profesi akuntan ditemukan dalam penelitian ini, seharusnya mereka dapat diwawancarai untuk dikonfirmasi lebih lanjut terkait hal ini, mereka adalah dosen yang mengajar di kelas, saudara, teman dan keluarga selain orang tua saja yang menyarankan mereka untuk studi pada jurusan akuntansi agar hasil penelitian yang diperoleh informasinya lebih banyak.

Saran yang dapat diberikan dalam penelitian ini adalah sebagai berikut:

1. Peneliti selanjutnya dapat menambahkan informan seperti: dosen, teman dan saudara yang berada di sekitar calon mahasiswa agar dapat menggali informasi yang lebih luas lagi tentang kuliah dan profesi akuntan.

2. Peneliti selanjutnya dapat mengambil studi kasus yang berbeda, penelitian tentang persepsi akuntansi tidak hanya dilakukan di perguruan tinggi dan SMA tetapi dapat mengambil di tempat lain yang lebih luas untuk mendapatkan hasil yang berbeda.

3. Peneliti selanjutnya dapat mengambil topik tentang pengaruh internet (media sosial) terhadap minat calon mahasiswa untuk melanjutkan studi pada jurusan akuntansi.

\section{Daftar Pustaka}

Budiarti, D. S. 2015. Pengaruh Lingkungan Teman Sebaya, Kondisi Sosial Ekonomi Orang Tua, Dan Peran Guru Terhadap Minat Melanjutkan Studi Ke Perguruan Tinggi. Skripsi Fakultas Ekonomi Universitas Negeri Semarang.

Damarjati, W. 2017. Minat Siswa Melanjutkan Studi Ke Perguruan Tinggi Ditinjau Dari Tingkat Pendapatan Orang Tua Dan Motivasi Belajar Pada Siswa Kelas Xii Ips SMA Negeri 1 Andong Tahun Ajaran 2016/2017. Skripsi. Program Studi Ekonomi Akuntansi Fakultas Keguruan Dan Ilmu Pendidikan Universitas Muhammadiyah. Surakarta.

Djaali. 2011. Psikologi Pendidikan. Jakarta : Bumi Aksara.

Erwanto, G.V., Y.K. Feliana dan Y. Sugiarti. 2015. Pengaruh Persepsi Mahasiswa Terhadap Pemilihan Jurusan Akuntansi. Calyptra: Jurnal Ilmiah Mahasiswa Universitas Surabaya 4(2).

Fauziah, N.S. 2017. Pengaruh Prestasi Belajar Akuntansi, Lingkungan Teman Sebaya, Dan Persepsi Siswa Tentang Mata Pelajaran Akuntansi Terhadap Minat Melanjutkan Studi Ke Prodi Akuntansi Pada Siswa Kelas XII IPS SMA Negeri 1 Depok Tahun Ajaran 2017/2018. Skripsi. Fakultas Ekonomi Universitas Negeri. Yogyakarta.

Germanou, E., T. Hassall dan Y.Tournas. 2009. Students' perceptions of accounting profession: work value approach, Asian Review of Accounting 17(2): 136-148. 
Handayani, A. 2017. Analisis Bauran Pemasaran Terhadap Keputusan Mahasiswa Memilih Program Studi (Studi Di Fakultas Ekonomi Universitas Bojonegoro). Tesis. Program Studi Magister Administrasi Pendidikan Sekolah Pasca Sarjana Universitas Muhammadiyah Surakarta

Hsiao, J. dan S.P.D.C.C. Nova. 2016. Generational Approach to Factors Influencing Career Choice in Accounting. Castro Casa Nova DOI: $\quad$ 10.1590/1808057x201602980. R. Cont. Fin. USP, São Paulo 27(72): 393-407.

Kharisma, G. 2017. 5 Jurusan Soshum yang Paling Banyak Diminati di PTN.www. kompasiana.com. 6 November 2018 (17:12). Halaman 6.

Kotler, P. 2009. Manajemen Pemasaran. Jakarta : Erlangga

Kusuma, L.A.W. 2016. Faktor-Faktor Yang Mempengaruhi Pengambilan Keputusan Mahasiswa Dalam Memilih Program Studi Pendidikan Akuntansi Di Universitas Negeri Semarang. Skripsi. Fakultas Ekonomi Universitas Negeri. Semarang.

Mahartika, L. 2019. Macam-macam Profesi akuntan, Kamu yang Mahasiswa Wajib Tahu. www.liputan6.com. 15 Januari 2019 (12.35) Halaman 3

Malthus, S dan C. Fowler. 2009. Perceptions of accounting: a qualitative New Zealand study. Pacific Accounting Review 1(1): 2647.

Nadlari, M.T.J. 2015. Persepsi Mahasiswa Akuntansi Mengenai Faktor-Faktor Yang Membedakan
Pemilihan Karir. Skripsi. Fakultas Ekonomi dan Bisnis Universitas Pendidikan Ganesha Singaraja.

Rahayu, S. 2013. Minat Siswa Melanjutkan Studi Ke Perguruan Tinggi Ditinjau Dari Prestasi Belajar, Motivasi Belajar, Dan Status Sosial Ekonomi Orang Tua Pada Siswa Kelas Xi Ips SMA Negeri Jumapolo Tahun Ajaran 2012/2013. Skripsi. Program Studi Pendidikan Ekonomi Akuntansi Fakultas Keguruan Dan Ilmu Pendidikan Universitas Muhammadiyah. Surakarta.

Sari, N .2014. Pengaruh Status Ekonomi Keluarga Terhadap Minat Pendidikan Perguruan Tinggi Siswa Kelas XII SMKN Pontianak. Artikel Penelitian. Program Studi Pendidikan Ekonomi Bkk Akuntansi Jurusan Pendidikan Ilmu Pengetahuan Sosial Fakultas Keguruan Dan Ilmu Pendidikan Universitas Tanjungpura Pontianak.

Saputra, J. 2017. Upaya Guru Bimbingan Konseling Dalam Meningkatkan Minat Melanjutkan Ke Perguruan Tinggi Di SMA Negeri 1 Membalong Kelas XII Tahun Ajaran 2016/2017. Skripsi. Jurusan Bimbingan Dan Konseling Universitas PGRI. Yogyakarta.

Sulistyawati, A.I, Nina, R dan Netty, S. 2013. Persepsi Mahasiswa Akuntansi Mengenai Faktor-Faktor Yang Mempengaruhi Pemilihan Karir. Jurnal Dinamika Akuntansi. ISSN 2085-4277 5(2): 86-98.

Sugiyono. 2015. Memahami Penelitian Kualitatif. Badung: Alfabeta

Suryani, W dan P. Ginting. 2013. FaktorFaktor Yang Mempengaruhi Keputusan Mahasiswa Memilih Fakultas Ekonomi Universitas Islam 
Sumatera Utara Al Munawaroh Medan. Modernisasi 341(9).

Sutrisno, E. 2017. Pengaruh Layanan Informasi Studi Lanjut Terhadap Minat Masuk Perguruan Tinggi Siswa SMK Negeri 2 Boyolangu. Simki-Pedagogia 01(08) ISSN : AAAA-AAAA.

Ichsan, M.I. 2017. SBMPTN, Survei Tempo Ihwal 12 Fakultas Favorit PTN dan PTS. https://nasional.tempo.co. 7 November 2018 (10.30) Halaman 7.

Ticoi, C.F dan N. Albu. 2018. What factors affect the choice of accounting as a career? The case of Romania. Accounting and Management Information Systems 17(1): 137-152
Saepulloh, R. 2017. Jumlah Akuntan di Indonesia Masih Minim. wartaekonomi.co.id. 6 Desember 2018 (10:36) Halaman 4

Syah, M. 2009. Psikologi Belajar. Jakarta: PT. Raja Grafindo Persada.

Yudhantoko, M.B. 2013. Persepsi Mahasiswa Akuntansi Mengenai Minat Dalam Pemilihan Karir Sebagai Akuntan Perusahaan. Skripsi. Fakultas Ekonomika dan Bisnis Universitas Diponegoro. Semarang.

Yulistara, A. 2018. 10 Profesi Paling Membosankan di Dunia. www.cnbcindonesia.com. 3 Februari 2019 (11.48) Halaman 8 